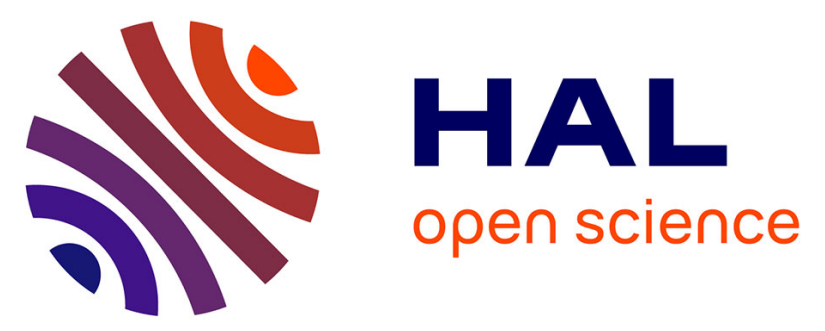

\title{
Better Integrating Driver Education and Training within a New Graduated Driver Licensing Framework in North America
}

Daniel R. Mayhew, Allan F. Williams, Robyn Robertson, Ward Vanlaar

\section{- To cite this version:}

Daniel R. Mayhew, Allan F. Williams, Robyn Robertson, Ward Vanlaar. Better Integrating Driver Education and Training within a New Graduated Driver Licensing Framework in North America. RTS - Recherche Transports Sécurité, 2017, Formation à la conduite, 2016 (01-02), pp.97-105. 10.4074/S0761898016002090 . hal-01670589

\author{
HAL Id: hal-01670589 \\ https://hal.science/hal-01670589
}

Submitted on 21 Dec 2017

HAL is a multi-disciplinary open access archive for the deposit and dissemination of scientific research documents, whether they are published or not. The documents may come from teaching and research institutions in France or abroad, or from public or private research centers.
L'archive ouverte pluridisciplinaire HAL, est destinée au dépôt et à la diffusion de documents scientifiques de niveau recherche, publiés ou non, émanant des établissements d'enseignement et de recherche français ou étrangers, des laboratoires publics ou privés. 


\title{
Better Integrating Driver Education and Training within a New Graduated Driver Licensing Framework in North America
}

\section{Une meilleure intégration de l'éducation et de la formation des conducteurs par un nouveau cadre d'accès gradué à la conduite en Amérique du Nord}

\author{
Daniel R. Mayhew · Allan F. Williams · Robyn Robertson - Ward Vanlaar \\ C IFSTTAR et Éditions NecPlus 2016
}

Résumé Les systèmes d'acquisition de permis de conduire par étape (Graduated Driving License - GDL) et l'éducation des conducteurs, deux mesures de sécurité envers les adolescents et les nouveaux conducteurs, ont été largement adoptés en Amérique du Nord bien que souvent de manière séparée. L'éducation des conducteurs est antérieure à l'accès graduel à la conduite et est restée relativement inchangée depuis sa création, alors que le système GDL a connu des améliorations bien que le rythme du changement ait ralenti.

L'accès graduel à la conduite a démontré son efficacité en termes de sécurité ce qui n'a pas été le cas de l'éducation des conducteurs bien que quelques études récentes aient données des résultats prometteurs en termes de sécurité aussi bien avec des programmes traditionnels que non traditionnels.

Ce document plaide en faveur d'une éducation des conducteurs intégrée avec un systéme GDL amélioré pour mieux répondre au risque d'accident élevé des conducteurs adolescents. Il recommande que l'éducation des conducteurs soit multiphase et plus étroitement alignée sur la structure hiérarchique du GDL et que les Normes nationales d'instruction des conducteurs (NDES)

\footnotetext{
Daniel R. Mayhew $(\bowtie)$

Traffic Injury Research Foundation 171 Nepean Street, Suite 200 Ottawa, Ontario K2P OB4, Canada

e-mail : danm@tirf.ca

Allan F. Williams $(\triangle)$

8200 Beech Tree Rd. Bethesda MD 20817, Etats-Unis

e-mail : allan.f.williams@gmail.com

Robyn Robertson $(\triangle)$

Traffic Injury Research Foundation 171 Nepean Street, Suite 200

Ottawa, Ontario K2P OB4, Canada

e-mail : robynr@tirf.ca

Ward Vanlaar $(\bowtie)$

Traffic Injury Research Foundation 171 Nepean Street, Suite 200

Ottawa, Ontario K2P OB4, Canada

e-mail :Wardv@tirf.ca
}

deviennent la nouvelle « norme » pour leur éducation. Il fournit également des conseils pour améliorer le contenu et la prestation de l'éducation du conducteur, y compris l'utilisation de techniques d'enseignement et de formation non traditionnelles.

Les efforts à venir visant à intégrer et à améliorer le système GDL et l'éducation des conducteurs doivent toutefois faire l'objet de recherches en utilisant des modèles d'évaluation solides pour s'assurer qu'ils ont des effets sur la sécurité.

Mots clés accès graduel à la conduite - GDL · éducation du conducteur · entraînement du conducteur · nouveaux conducteurs · conducteurs adolescents · mesures de sécurité

Abstract Graduated Driver Licensing (GDL) and driver education are two safety measures for teen and new drivers that have been widely adopted in North America, often in isolation from one another. Driver education pre-dated GDL and has remained relatively unchanged from its inception, whereas GDL has undergone enhancements although the pace of change has slowed down. GDL has proven safety effectiveness which has not been the case for driver education, although a few recent studies have had promising results on the safety value of both traditional and nontraditional programs.

This paper makes the case for integrating driver education with enhanced GDL to better address the elevated crash risk of teen drivers. It recommends that driver education be multi-phased and more closely aligned with the tiered structure of GDL and that the National Driver Education Standards (NDES) become the new "norm" for driver education. It also provides guidance for improving the content and delivery of driver education, including the use of nontraditional teaching techniques and training approaches.

Future efforts to integrate and improve GDL and driver education, however, need to be researched using solid evaluation designs to ensure they have safety effects and contribute to GDL's overall success. 
Keywords Graduated Driver Licensing · GDL · Driver education · Driver training - New drivers - Teen drivers . Safety measures for teens

\section{Introduction}

This paper discusses the rationale for, history of, and recent developments with, GDL and driver education and training, two safety measures that have been widely adopted in North America to address the elevated crash risk of teen and new drivers. It also describes a new GDL Framework in which these two safety measures are better integrated to reinforce an optimal GDL program.

\section{Graduated Driver Licensing}

GDL involves a multi-staged system of licensing in which novice drivers are gradually exposed to driving situations over an extended period of time spent in low-risk environments. It typically consists of three stages: a learner stage of at least several months in which driving is only allowed under supervision; an intermediate or provisional stage allowing independent driving with restrictions/conditions such as on night driving and passenger limits; and a full, unrestricted, license.

The history of GDL in the United States (US) has been recently tracked by Williams et al. [1]. It can be summarized into several time periods, which includes key dates for both the US and Canada:

- 1970s: the concept of a GDL system, which would allow novice drivers to gain driving experience under low risk conditions, emerged for discussion and debate in Canada and the US;

- 1980s and early 1990s: Initially unpopular but a few states had an extended learner period or a night restriction prior to 1994 ;

- 1994: Ontario and then Nova Scotia implemented GDL programs as did Florida in 1996;

- 1996-2006: all jurisdictions implemented some form of GDL, including at least one essential feature such as extended learner stage, night restriction, passenger limits;

- 1998-2015: in the US 158 amendments of original legislation adding or strengthening these features, plus supervised hours requirements; enhancements to GDL also introduced in some Canadian provinces;

- 2010-present: major slowdown in further upgrades of these GDL features.

Today, the age of entry into the learner stage of GDL in the US varies from 14 to 16 and the required holding period is generally 6 to 12 months. Required supervised practice hours generally range from 30 to 70 hours. Intermediate license ages range from $14 \frac{1}{2}$ to 17 with night restriction starting times ranging from $8 \mathrm{pm}$ to $1 \mathrm{am}$. Passenger restrictions allow from zero to three passengers and the age of graduation to a full license varies from 16 to 18. In Canada, GDL applies to all novice drivers regardless of age, and the stages are time-based so stage restrictions/conditions are not lifted at age 17 or 18 , which is typically the case in the US

GDL has not only been a popular policy but also a successful one. Studies in North America have indicated that GDL is associated with substantial decreases in crashes among 16-year olds and positive but lesser effects among 17-year olds [2]. Effects at ages 18 and 19 are not resolved [3]. Positive, negative, and neutral effects at these ages have all been reported in the literature $[4,5,6,7,8]$. However, although all 50 states and the District of Columbia have some form of GDL in place, there is substantial variation in the strength and completeness of the systems and it is well-established that stronger programs have more positive effects $[5,9,10]$. All but a handful of US jurisdictions have minimum required supervised driving hours and night and passenger restrictions. The Insurance Institute for Highway Safety [11] provides a GDL "calculator" that allows states to estimate potential reductions in 15-17-year old driver fatal crash rates if they had the most stringent provisions found in the US. Based on these calculations state reductions ranging from $17 \%$ to $63 \%$ would be possible, yielding an annual savings of more than 500 lives.

\section{Driver Education}

Driver education is designed to teach new drivers the rules of the road and the driving skills to prepare for the road test and obtain a driver's license. It is recognized and promoted as a safety measure that dates back to the early 1930s in the US and Canada. Today and for many years, most jurisdictions in the US, Canada, and elsewhere have delivered driver education in high schools and/or commercial driving schools. And, a recent US National Young Driver survey administered in public schools revealed that almost $80 \%$ of students with a driver's license reported participating in formal driver education [12]. These programs typically consist of both "theoretical" instruction in the classroom and "practical" training in the vehicle [13]. Although there are similarities in traditional driver education programs, there is considerable variation in their content and delivery across jurisdictions as well as within some jurisdictions. In some cases, driver education is a mandatory requirement for getting a license prior to age 18 and in others it is not compulsory, although provisions may be in place that encourage teens to take driver education (e.g., obtain a learner hours of supervised driving practice required). 
Although driver education provides an efficient means to learn how to drive evaluations have failed to show that such traditional programs (e.g. 30 hours in classroom and 6 to 8 hours "behind the wheel") produce safer drivers $[14,15,16$, $17,18,19,20,21,22,23,24]$. This is the case in evaluations of the safety effects of traditional driver education that have been conducted internationally, and not just in the US. Poor evaluation methods may be part of the reason for this, but even well-designed evaluations have produced findings that raise questions about the safety benefits of driver education. To illustrate, the DeKalb County, Georgia Randomized Control Trial (RCT) involved the development and evaluation of a specialized curriculum with over 70 hours of classroom, simulation, closed-course, and on-road training [25]. Despite having a very large sample of teen drivers randomly assigned to the new program, a more traditional program or to a control group, this investigation along with several subsequent reanalyses of the datasets failed to show a consistent favorable effect of driver education on collisions. Although one of the analyses in the original study reported that the new program was associated with fewer crashes in the first six months of driving this positive result has been hotly contested in the literature on methodological grounds $[18,25,26,27]$. The safety benefits of driver education have also been questioned because some driver education programs may inadvertently encourage earlier licensure, and consequently, result in crashes at an earlier age than would have been the case in the absence of training [26, 28]. As an outcome of the investigations conducted in the DeKalb study and by others, support and funding for driver education dramatically decreased at state and federal levels in the US. For several decades, driver education was no longer viewed as a priority safety measure $[20,29]$.

There have been a few recent evaluations of driver education programs that have further informed our understanding of their safety effects. A major investigation that was recently completed in Manitoba and Oregon has taken a more comprehensive approach than previous studies to evaluating driver education programs. This evaluation found modest but important improvements in intermediate measures such as safe driving knowledge, attitudes, motivations, skills, and behaviors, among course graduates relative to control groups who had not taken these programs [30]. Results based on a cross-sectional comparison of the driving records of 94,342 Oregon teen drivers also suggested that driver education in Oregon is associated with a $4.3 \%$ statistically significant reduction in collisions. The authors observed, however, that although efforts were taken in the Poisson regression analyses to control for key factors, such as age, sex, urban/rural location, and driving exposure, other factors unaccounted for in the analyses might explain part or all of these positive findings, and not driver education itself.
Another recent evaluation in Nebraska also reported that driver education was associated with small but statistically significant reductions in collisions. A descriptive epidemiological study [31] that examined a census of all teen drivers in Nebraska (151,880 teens) during an eight year period from 2003 to 2010 , found that teens taking driver education were less likely than teens not taking driver education to be involved in crashes during their first two years of driving. A hierarchical logistic regression showed, for example, that in year one of driving the driver education cohort had significantly fewer crashes than the non-driver education cohort $(11.1 \%$ versus $12.9 \%)$. The analysis suggested that the non-education group was 1.22 times more likely than the driver education group of crashing after taking into account key demographic factors such as age, sex, race/ethnicity, urbanicity and household income. This evaluation was a census of all Nebraska teen drivers receiving their provisional license during the study period meaning the large study population eliminated problems of reduced power due to small sample sizes. Similar to the major limitation of the Mayhew et al. evaluation [30], however, this study was not a true randomized, controlled experiment, as teens self-selected whether they took driver education or not. Although statistical controls were applied to account for key demographic differences between teens that took or did not take driver education, these statistical procedures did not fully compensate for the lack of random assignment.

The crash reduction effects for driver education reported in the Oregon and Nebraska studies are promising for several reasons. Both studies are recent and applied evaluation designs that improved upon earlier study designs, including the use of large populations rather than the small samples typically used in randomized studies, which are prone to sample attrition and reduced power. Both studies also controlled for key demographic variables, which was not always the case in earlier investigations. Both studies evaluated driver education programs that have features of traditional programs previously shown to be ineffective but also have enhancements, which might account for the safety effects. The Oregon program includes a "Parent Involvement Resource Guide" and a "Driver Education Risk Prevention Curriculum". The Nebraska driver education program includes competency-based courses, which evaluate students against established criteria and are taught by competency certified instructors. Finally, although both the Oregon and Nebraska studies have limitations primarily due to the lack of random assignment and only controlling for a few key factors, randomization of subjects is difficult and perhaps not feasible in driver education evaluation, especially when evaluating well-established programs delivered state-wide.

In recognition of the research on driver education, and in an effort to promote more uniformity in programs, there 
has emerged a concerted effort at the federal level and within the driver education leadership in the US to improve traditional programs. This resurgence of interest is perhaps best exemplified by the recently updated National Driver Education Standards (NDES) developed by the Association of National Stakeholders in Traffic Safety Education (ANSTSE) with assistance from the National Highway Traffic Safety Administration (NHTSA). The Standards document states that: "The goal of driver education and training is to transfer knowledge, develop skills, and enhance the disposition of the teen, so he/she can perform as a safe and competent driver, thereby contributing to the reduction of crashes, fatalities, and injuries." These National standards also provide guidance as to how traditional driver education programs should be substantially restructured to better achieve their safety goals $[32,33]$. As states adopt the new standards, research is needed to determine if safety goals have actually been achieved.

NHTSA has also introduced and supports a Driver Education Review program which allows relevant state authorities to have their state-approved driver education program assessed by a panel of experts against the NDES. This program is relatively new and only a few states have undergone this NHTSA-facilitated review, including Oregon, Maryland, Vermont, Delaware, Idaho, and Michigan.

\section{Integrated GDL and Driver Education}

GDL and driver education co-exist but they are seldom integrated. In fact, the advent of graduated licensing in the US and Canada in the 1990's had relatively little influence on existing driver education programs and in most cases both GDL and driver education operated independently, with the requirements for driver education being carried over from the previous pre-GDL period. A major challenge is to identify ways to integrate GDL and driver education to enhance the benefits of both. This challenge has certainly received some attention, but not much action in graduated licensing programs in North America and elsewhere. In this regard, a recent NHTSA-funded report taking a fresh look at driver education called for an expanded and integrated driver education and graduated licensing system with improved content, delivery mechanisms, and legal/administrative framework [21]. This report, however, did not provide much guidance as to ways to accomplish this goal.

To address the need to better integrate driver education and GDL, the current authors recently conducted a project to develop a comprehensive GDL Framework which proposes that driver education, licensing and testing requirements, as well as in-vehicle monitoring technology be integrated into an enhanced GDL program [34]. The GDL Framework illustrated below comprises evidence-based initiatives along with those that are largely unproven but make sense on logical grounds and are supported by expert opinion. This is similar to the situation several decades ago when the concept of GDL was initially developed and promoted. At that time, there was limited or no research on the safety effects of GDL and most of its components, with the exception of a night driving restriction which early studies had shown to have safety benefits. However, the concept of a GDL system that introduced beginners into the traffic environment while protecting them as they gained experience made sense on logical grounds. As jurisdictions implemented GDL and evaluated it, GDL emerged as a popular and successful policy with proven safety benefits.

The GDL Framework was developed via a review of literature related to these topics, an environmental scan of contacts in North America and worldwide to identify recent advances in young and novice driver programs, and a $1 \frac{1}{2}$ day international expert panel discussion to describe, discuss, and augment a proposed broad GDL Framework. Importantly, a high level of consensus was achieved by the expert panel in relation to many features of the Framework. These inputs resulted in a publication entitled "A New GDL Framework: Evidence Base to Integrate Novice Driver Strategies" [34].

Since the strength of the evidence in support of a specific component being recommended varies from strong to lesser or insufficient evidence, the illustration uses a gold star to denote components with a "sufficient evidence base"-e.g., applying to all beginner drivers, a night restriction. Other components are based on expert opinion having a solid logical basis for consideration. Although these lack strong empirical evidence they are recommended as part of the GDL Framework since they may reinforce GDL principles and operation but further research is needed to determine their safety effectiveness and/or the extent to which they contribute to the overall benefits of GDL.

As shown in the illustration, the GDL Framework applies to all beginner drivers, which is the case in a few GDL countries (e.g., Canada). The rationale for this policy is that novices of all ages are at risk because of their inexperience, and GDL is a system designed to deal with inexperience, not age per se. Evaluations are few in number but provide some evidence that GDL programs for older novices can also reduce crash involvement [35, 36, 37]. Young and novice drivers move through two restricted stages of licensing, including a learner and intermediate stage, before progressing to full licensure. All of the components of the Framework for each of these stages of licensing are described in detail in the main report [34]. In terms of driver education, which is the primary focus of this paper, the Framework proposes that jurisdictions should regulate 


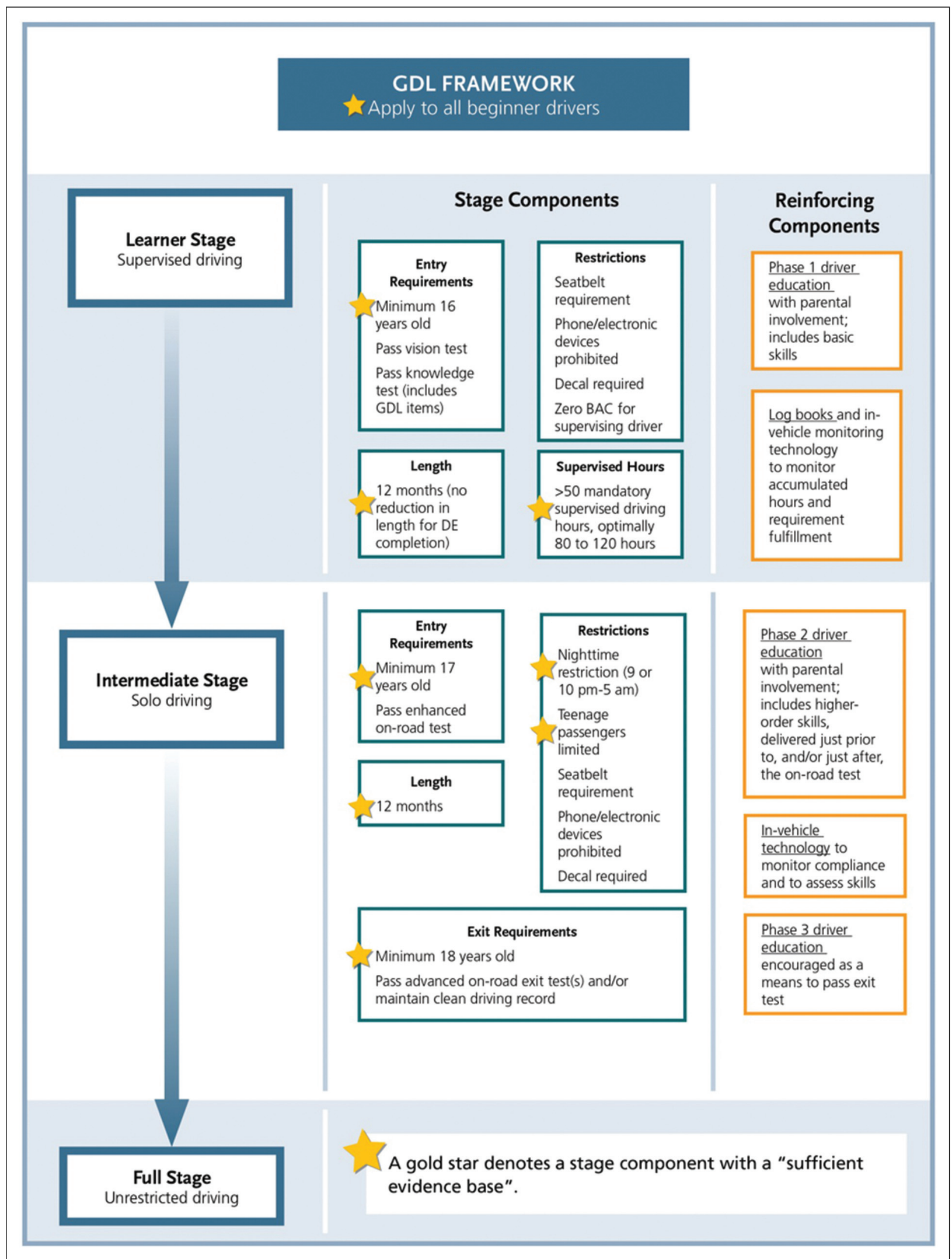

Fig. 1 GDL framework 
driver education to meet the NDES in a multi-phased approach, including an initial phase of driver education (Phase 1), which would include in-vehicle and theoretical instruction that teaches basic vehicle handling skills and rules of the road to learners. Phase 1 driver education for young learners should: be teen-oriented; include a mandatory parent orientation course and encourage parental involvement throughout the GDL process; include GDL rationale and requirements in the curriculum; provide end of course reports/debriefings to parents that include recommendations for areas that need improvement; and, provide information about available in-vehicle technologies that can enhance the safety of young and novice drivers. The completion of driver education should not result in a reduced length of time spent in the learner stage as previous research has shown this policy has safety dis-benefits [16, $21,23,38,39,40,41,42,43]$. Driver education in-vehicle hours could be applied to reduce the mandatory minimum supervised driving hours if they are set at 120 hours or more. Phase 2 driver education should be delivered just prior to the on-road test, or alternatively or in addition, in the first few months after the road test when teens are driving independently for the first time and experiencing their highest crash risk. This second phase of driver education would involve advanced instruction to teach safe driving procedures including perceptual and decision-making skills (could include hazard perception training and incorporation of driving in high-risk situations, such as highway driving) and should be jurisdiction-regulated and encouraged. In order to progress to a full, unrestricted license, intermediate license holders should be required to pass an advanced on-road or computer-based exit test that includes measures of higher-order driving skills such as hazard perception, situational awareness, and decision-making. This test provides incentive for novice drivers to obtain additional driving instruction (in the form of Phase 3 driver education) and practice during the intermediate stage, in order to attempt the exit test and obtain a full license.

The development of the GDL Framework was the first phase of a two phase study. In the second phase, a strategy to implement the new GDL Framework was formulated. Creating the implementation strategy involved two key steps. The first step was an environmental scan of recent initiatives to enhance GDL and teen driver safety in the United States and Canada. The second step was a $1 \frac{1}{2}$ day International Symposium involving invited participants who represented a broad cross-section of people responsible for licensing laws in their jurisdiction, researchers, highway safety advocates, and other stakeholders from the private sector (e.g., automobile insurance companies, technology providers, insurance companies). The objectives of the first day of the meeting were to orient attendees about the GDL Framework and its features, share success stories in a few jurisdictions that had recently enhanced their GDL programs; and, engage participants in more intensive discussions regarding the individual components in the GDL Framework. In the half day of discussions on the second day, a much smaller group was convened as an expert panel to finalize the top recommendations regarding which components from the GDL Framework should be selected for greater attention, and implementation strategies were discussed. Phase 1 driver education was identified as one of the components of the GDL Framework that should be put forward as holding the greatest potential for implementation. Phases 2 and 3 driver education were viewed as important but for future consideration. The full implementation plan emerging from this symposium is described in a publication entitled "A New GDL Framework: Planning for the Future" [44].

Even if driver education is better coordinated with the structure of graduated licensing by being multi-phased and by partnering with parents for supervised driving practice, such programs may not achieve their potential without further improvements to their content and delivery. Certainly, a step forward would be for driver education to upgrade its curriculum to include more GDL information ensuring that the rules and rationale for GDL are an important part of the "theoretical" component of the program. It is possible that driver education is too narrowly focused and fails to adequately address wider lifestyle issues which determine how drivers actually behave on the road and not how skilled they are at driving (i.e., what drivers actually do versus what drivers are capable of doing). In this context, the Goals for Driver Education (GDE) principles were originally developed by the European Union in the Guarding Automobile Drivers through Guidance, Education and Technology (GADGET) project $[45,46]$. The GDE Matrix provides a hierarchical schema of the driver's task, outlining the personal situation within which all drivers undertake driving, including preconditions, attitudes, abilities, demands, decisions and behavior, categorized into four levels: 1. Vehicle maneuvering; 2. Mastery of traffic situations; 3. Goals and context of driving; 4. Goals for life and skills for living. Traditional driver education programs in the US and Canada typically focus on levels one and two, and to some extent level three, without any or much focus on the fourth level, despite the fact that these higher levels are likely the major influences on teen driving behavior giving rise to their elevated crash risk. Although applying GDE principles to improve driver education makes sense on logical grounds, the safety effects have not yet been evaluated.

Resilience training to address lifestyle factors, insight training to address optimism bias, and the Probationary or "P" Drivers project, which aims to effect behavior change among young newly licensed drivers, currently being 
evaluated in Australia, have modest evidence and show promise [47, 48, 49, 50]. Further research, however, is needed to determine whether, and how, to integrate these into improved multi-phased driver education that is better coordinated with graduated licensing (i.e., what is the proper mixture of these safety measures).

Driver education should also use the best teaching methods and learning principles. For example, computerbased instruction and driving simulation, including on lowcost PC-based systems, provide a protected way of exposing teens to the hazardous driving situations that contribute most to the elevated crash risk among adolescents. These methods provide a more efficient and possibly more effective means of transferring knowledge, attitudes, and skills, especially those related to hazard perception, than do didactic lectures, dated safety videos, and only minimal hours of in-vehicle training on-road $[51,52,53,54,55,56,57]$. And, in this regard, nontraditional computer-based driver training programs such as Adept Driver's teenSMART, a crash reduction program, and RAPT, a risk awareness and perception training program, have been shown to improve driving performance and reduce collisions [58, 59, 60, 61, 62]. Accordingly, there is at least limited evidence from a few solid studies suggesting a positive effect of some forms of nontraditional driver education/training of hazard perception on collisions [58, 62].

Teaching techniques, such as commentary driving (having novice drivers comment on the hazards and factors they take into account while driving), which has been shown to improve hazard detection and response, at least in a simulated driving environment, should also be considered $[34,63,64,65,66]$. This is also the case for in-car technologies (e.g., systems that warn about unsafe driving such as speeding) to train and monitor young drivers, which have been shown to significantly reduce the occurrence of risky driving [34, 67, 68, 69, 70, 71, 72]. It is important as well to match the learning experiences to the novices' needs and skill level, which speaks to better testing and diagnostic assessments by means of, for example, improved driving tests and computer-based training and testing [34, 73, 74].

\section{Conclusion}

GDL and driver education are two safety measures for teen and new drivers that have been widely adopted in North America, often in isolation from one another. Driver education pre-dated GDL and has remained relatively unchanged from its inception, whereas GDL has undergone enhancements although the pace of change has slowed down. There has been a recent resurgence of interest in driver education, perhaps best exemplified by the formation of ANSTSE and the development of the NDES. GDL has proven safety effects which has not been the case for driver education, although a few recent studies produced promising results on the safety value of both traditional driver education and nontraditional programs.

This paper makes the case for integrating driver education with GDL along with other reinforcing safety measures to better address the elevated crash risk of teen drivers. It recommends that driver education be multi-phased and more closely aligned with the tiered structure of GDL and that the NDES become the new "norm" for driver education. It also provides guidance for improving the content and delivery of driver education, including the use of nontraditional teaching techniques and training approaches.

Future efforts to integrate and improve GDL and driver education, however, need to be researched using solid evaluation designs to ensure they have safety effects and contribute to GDL's overall success.

Acknowledgement We greatly appreciate the support provided to us by the National Safety Council and the National Highway Traffic Safety Administration for Phases 1 and 2 of the GDL Framework project.

\section{Reference}

1. Williams, AF, McCartt, T, Sims, LB (2016) History and current status of state graduated driver licensing (GDL) laws in the United States. Journal of Safety Research 56: 9-15.

2. Williams, AF, Tefft, BC, Grabowski, JG (2012) Graduated driver licensing research, 2010-present. Journal of Safety Research 43: 195-203.

3. Masten, SV, Thomas, FD, Korbelak, KT, Blomberg, RD et al. (2014) A meta-analysis of graduated driver licensing programs and components in the United States. Draft report.

4. Masten, SV, Foss, R, Marshall, S (2011) Graduated driver licensing and fatal crashes involving 16- to 19-year old drivers. Journal of the American Medical Association 306: 1099-1103.

5. McCartt, AT, Teoh, ER, Fields, M, Braitman, KA, Hellinga, L.A (2010) Graduated licensing laws and fatal crashes of teenage drivers: a national study. Traffic Injury Prevention 11: 240-248.

6. Morrisey, MA, Grabowski, DC (2010) Gas prices, beer taxes, and GDL programmes: effects on auto fatalities among young adults in the US. Applied Economics 1-10 (iFirst).

7. Vanlaar, W, Mayhew, D, Marcoux, K, Wets, G, Brijs, T, Shope, J (2009) An evaluation of graduated driver licensing programs in North America using a meta-analytic approach. Accident Analysis and Prevention 41: 1104-1111.

8. Zhu, M, Cummings, P, Chu, H, Coben, J, Li, G (2013) Graduated driver licensing and motor vehicle crashes involving teenage drivers: an exploratory age-stratified meta-analysis. Injury Prevention 19: 49-57.

9. Fell, JC, Jones, K, Romano, E, Voas, R (2011) An evaluation of graduated driver licensing effects on fatal crash involvements of young drivers in the United States. Traffic Injury Prevention 12: 423-431.

10. Steadman, M, Bush, JK, Thygersons, SM, Barnes, MD (2014) Graduated driver licensing provisions: an analysis of state policies and what works. Traffic Injury Prevention 15: 343-349. 
11. Insurance Institute for Highway Safety (2014) GDL Crash Calculator. Retrieved from: www.iihs.org.

12. Curry, AE, Garcia-Espana, F, Winston, FK, Ginsburg, K, Durbin, WR (2012) Variation in teen driver education by state requirements and sociodemographics. Pediatrics 129(3): 453-457.

13. Chaudhary, N, Bayer, L, Ledingham, K, Casanova, T (2011) Driver Education Practices in Selected States. Washington, DC: National Highway Traffic Safety Administration.

14. Christie, R (2011) The Effectiveness of Driver Training as a Road Safety Measure: A Review of the Literature (2011 Edition/Update). Report prepared for the Royal Automobile Club of Victoria (RACV) Ltd., Noble Park, Victoria.

15. Engstrom, I, Gregersen, NP, Hernetkoski, K, Keskinen, E, Nyberg, A (2003) Young novice drivers, driver education and training (Literature review, VTI-rapport 491A). Linköping, Sweden: Swedish National Road and Transport Research Institute.

16. Lonero, LP, Mayhew, DR (2010) Large-Scale Evaluation of Driver Education Review of the Literature on Driver Education Evaluation: 2010 Update. Washington, DC: AAA Foundation for Traffic Safety.

17. Mayhew, DR, Simpson, HM (2002a) The safety value of driver education and training. Injury Prevention 8(Suppl. II): ii3-ii8.

18. Mayhew, DR, Simpson, HM (1998) Effectiveness and role of driver education in a graduated licensing system. Journal of Public Health Policy 19(1): 51-67.

19. Roberts, I, Kwan, I et al. (2002) School-based driver education for the prevention of traffic crashes. The Cochrane Library, Issue 1, Oxford, England.

20. Simpson, HM (2003) The evolution and effectiveness of graduated licensing. Journal of Safety Research 34(1): 25-34.

21. Thomas, FD III, Blomberg, RD, Donald, L, Fisher, DL (2012) A Fresh Look at Driver Education in America. Report No. DOT HS 811 543. Washington, DC: National Highway Traffic Safety Administration.

22. Vernick, JD, Li, G, Ogaitis, S, MacKenzie, EJ, Baker, SP, Gielen, AC (1999) Effects of high school driver education on motor vehicle crashes, violations, and licensure. American Journal of Preventive Medicine 1S: 16.

23. Williams, AF, Preusser, DF, Ledingham, KA (2009) Feasibility Study on Evaluating Driver Education Curriculum. Washington, DC: National Highway Traffic Safety Administration.

24. Woolley, J (2000) In car driver training at high schools: a literature review. Walkerville, South Australia: Safety Strategy, Transport SA.

25. Stock, JR, Weaver, JK, Ray, HW, Brink, JR, Sadof, MG (1983) Evaluation of Safe Performance Secondary School Driver Education Curriculum Demonstration Project. Washington, DC: US Department of Transportation, National Highway Traffic Safety Administration.

26. Mayhew, DR., Simpson, HM (1996) Effectiveness and Role of Driver Education in a Graduated Licensing System. Ottawa, Ontario: Traffic Injury Research Foundation.

27. Peck, RC (2010) Do driver training programs reduce crashes and traffic violations? - A critical examination of the literature. IATSS Research 34: 63-71.

28. Robertson, L S (1980) Crash involvement of teenaged drivers when driver education is eliminated from high school. American Journal of Public Health 70(6): 599-603.

29. Nichols, JL (2003) A review of the history and effectiveness of driver education and training as a traffic safety program. Washington, DC: National Transportation Safety Board.

30. Mayhew, DR, Lonero, L, Marcoux, K, Wood, K, Simpson, H, Vanlaar, W, Clinton, K (2014a) Evaluation of Driver Education in Manitoba and Oregon. Washington DC: AAA Foundation for Traffic Safety.
31. Shell, DF, Newman, IM, Cordova-Cazar, AL, Heese, JM (2015) Driver education and teen crashes and traffic violations in the first two years of driving in a graduated licensing system. Accident Analysis and Prevention 82: 45-52.

32. NHTSA (2011) Novice Teen Driver Education and Training Administrative Standards. Washington, DC. National Highway Traffic Safety Administration.

33. NHTSA (2017, in publication). Novice Teen Driver Education and Training Administrative Standards (NTDETAS) 2017 Revision. Washington, D.C.: National Highway Traffic Administration.

34. Mayhew, DR, Williams, AF, Pashley, C (2014b) A New GDL Framework: Evidence Base to Integrate Novice Driver Strategies. Ottawa, Ontario: Traffic Injury Research Foundation.

35. Williams, AF, Chaudhary, NK, Tefft, BC, Tison, J (2010) Evaluation of New Jersey's graduated driver licensing program, Traffic Injury Prevention 11: 1-7.

36. Mayhew, DR, Simpson, HM, Singhal, D (2005) Best Practices for Graduated Driver Licensing in Canada. Ottawa, Canada: Traffic Injury Research Foundation.

37. Healy, D, Catchpole, J, Harrison, W (2012) Victoria's graduated licensing system evaluation interim report. Victoria, Australia: VicRoads.

38. Hirsch, P, Maag, Y, Laberge-Nadeau, C (2006) The role of driver education in the licensing process in Quebec. Traffic Injury Prevention 7: 130-142.

39. Lewis (2010) Crash involvement during the different phases of the New Zealand Graduated Driver Licensing System (GDLS). Journal of Safety Research 41(4): 359-365.

40. Mayhew, DR, Simpson, HM, Pak, A (2002b) Ontario graduated licensing system evaluation-2002. Toronto, Ontario: Ontario Ministry of Transportation.

41. Mayhew, DR (2007) Driver education and graduated licensing in North America: Past, present, and future. Journal of Safety Research 38(2): 229-235.

42. Williams, A, Mayhew, D (2008) Graduated licensing and beyond. American Journal of Preventative Medicine 35(3 Suppl): 324-33.

43. Wiggins, S (2004) Graduated licensing program: interim evaluation report-Year 3. Victoria, British Columbia: Insurance Corporation of British Columbia.

44. Mayhew, DR, Williams, AF, Robertson, RR (2016a) A New GDL Framework: Planning for the Future. Ottawa, Ontario: Traffic Injury Research Foundation.

45. Christ, R, Delhomme, P et al. (1999) GADGET. Guarding Automobile Drivers through Guidance Education and Technology. Vienna, Austria: Austrian Road Safety Board.

46. Hattakka, M, Kestinen, E, Baughan, C (2003) Basic Driver Training: New Models. EU-Project. Torku, Finland: University of Torku.

47. Gregersen, NP (1996) Young drivers' overestimation of their own skill-An experiment on the relation between training strategy and skill. Accident Analysis \& Prevention 28(2): 243-250.

48. Senserrick, T et al. (2009) Young driver education programs that build resilience have potential to reduce road crashes. Pediatrics 124(5): 1287-1292.

49. Senserrick, T, Swinburne, GC (2001) Evaluation of an Insight Driver-Training Program for Young Drivers. Melbourne, VIC, Australia: Monash University Accident Research Centre.

50. Seymour, R (2014, pers. com.) Manager of the Road User Access and Mobility Department at VicRoads in Victoria, Australia

51. Cox, CV, Wharam, R, Cox, DJ (2003) Does virtual reality driving simulation training transfer to on-road driving in novice drivers? A pilot study. Chronicle for Driver Education Professionals 57(1): 9, $21-24$. 
52. de Groot, S, Centeno Ricote, F, de Winter, JCF (2012) The effect of tire grip on learning driving skill and driving style: A driving simulator study. Transportation Research Part F: Traffic Psychology and Behaviour 15(4): 413-426.

53. Fisher, D, Pollatsek, A, Pradhan, A (2006) Can novice drivers be trained to scan for information that will reduce their likelihood of a crash? Injury Prevention 12(1): i25-i29.

54. Hirsch, P, Bellavance, F (2016) Pilot Project to Validate the Transfer of Training of Driving Skills Learned on a High Fidelity Driving Simulator to On-Road Driving. Final Report (CIRRELT-2016-15). DOI: 10.13140/RG.2.1.5092.6483.

55. Anuj, Pradhan, Masserang, KM, Divekar, G, Reagan, I, Thomas, FD, Blomberg, R, Pollatsek, A, Fisher, D (2009) Attention maintenance in novice drivers: Assessment and training. In Proceedings of the International Driving Symposium on Human Factors in Driver Assessment, Training, and Vehicle Design, NIH Public Access, pp. 349.

56. Rosenbloom, T, Eldror, E (2014) Effectiveness evaluation of simulative workshops for newly licensed drivers. Accident Analysis \& Prevention 63: 30-36.

57. Vlakveld, WP (2005)The use of simulators in basic driver training. SWOV, Institute for Road Safety Research. The Netherlands.

58. Mayhew, DR, Robertson, R, Hing, MM, Vanlaar, W (2016b) White Paper on Adept Driver's TeenSMART program: Safety Performance. Ottawa, Ontario: Traffic Injury Research Foundation.

59. Garay-Vega, L, Fisher, DL, Pollatsek, A (2007) Hazard anticipation of novice and experienced drivers: Empirical evaluation on a driving simulator in daytime and nighttime conditions. Transportation Research Record: 1-7.

60. Fisher, DL (2008) Evaluation of PC-based novice driver risk awareness. Washington, DC, US: National Highway Traffic Safety Administration.

61. Pradhan, AK, Fisher, DL et al. (2006) Risk perception training for novice drivers - Evaluating duration of effects of training on a driving simulator. Highway Safety: Law Enforcement; Alcohol; Driver Training; Safety Planning and Management; Commercial Vehicles; and Motorcycles: 58-64.

62. Thomas, FD, Rilea, SL, Blomberg, RD, Peck, RC, Korbelak, KT (2016) Evaluation of the safety benefits of the risk awareness and perception training program for novice teen drivers (Report No. DOT HS 812 235). Washington, DC: National Highway Traffic Safety Administration.

63. Cantwell, SR, Isler, RB, Starkey, NJ (2013) The effects of road commentary training on novice drivers' visual search commentary training on novice behavior. A preliminary investigation.
Proceedings of the Australasian Road Safety Research, Policing and Education Conference, August, Brisbane, Queensland.

64. Crundall, D, Andrews, B, van Loon, E, Chapman, P (2010) Commentary training improves responsiveness to hazards in a driving simulator. Accident Analysis \& Prevention 42(6): 2117-24.

65. Isler, RB, Starkey, NJ, Williamson, AR (2009) Video-based road commentary training improves hazard perception of young drivers in a dual task. Accident Analysis \& Prevention 41(3): 445-52.

66. Romoser, MRE, McDonald, C, Pradhan, AK, Goodwin, A, Lerner, $\mathrm{N}$ (2014) Learning to drive safely: A systematic review of hazard recognition skills in young novice drivers. Paper presented at the mid-year meeting of the Transportation Research Board Young Driver Subcommittee, Woods Hole, MA.

67. Bolderkijk, JW, Knockaert, J, Steg, EM, Verhoef, ET (2011) Effects of pay-as-you-drive vehicle insurance on young drivers' speed choice: Results of a Dutch field experiment. Accident Analysis \& Prevention 43: 1181-1186.

68. Farmer, CM, Kirley, BB, McCartt, AT (2010) Effects of in-vehicle monitoring and the driving behavior of teenagers. Journal of Safety Research 41(1): 39-45.

69. Horrey, WJ, Lesch, MF, Dainoff, MJ, Robertson, MM, Noy, I (2012) On-board safety monitoring systems for driving: Review, knowledge gaps, and framework. Journal of Safety Research 43(1): $49-58$.

70. Lerner, N, Jenness, J, Singer, J, Klauer, S, Lee, S, Donath, M, Manser, M, Ward, N (2010) An Exploration of Vehicle-Based Monitoring of Novice Teen Drivers: Final Report. National Highway Traffic Safety Administration (NHTSA).

71. McGehee, DV, Raby, M, Carney, C, Lee, JD, Reyes, ML (2007) Extending parental mentoring using an event-triggered video intervention in rural teen drivers. Journal of Safety Research 38: 215-217.

72. Toledo, T, Musicant, O, Lotan, T (2008) In-vehicle data recorders for monitoring and feedback on driver's behaviour. Transportation Research Part C 16: 320-331.

73. Mayhew, DR (2006) The Future of Driver Education. In: Driver Education: The Path Ahead. Transportation Research Circular, Number E-C101. Transportation Research Board of the National Academies.

74. Transportation Research Board (2006) Driver Education: The Path Ahead. Transportation Research Circular, Number E-C101. Transportation Research Board of the National Academies. 
